\title{
Deizme Götüren Sebepler
}

\section{Reasons Leading to Deism}

\author{
Dr. Öğr. Üyesi Yasin ULUTAŞ ${ }^{1} 1$
}

Öz

Vahiy ve akıl Allah'ın insana bahşettiği en önemli iki bilgi kaynağıdır. İnsan kendi alanı içerisinde birini diğerine mahkûm etmeden bu iki bilgi kaynağına yer verdiği takdirde insanlık büyük başarılar elde edecektir. İnsan bazen bu iki bilgi kaynağını birini diğerine karşı silah olarak kullanmıştır. Orta çağda özellikle Hıristiyanlık dinini temsil eden kilise ve bağlı otoriteler tahrif ettikleri dini kullanarak toplumu sömürmüşlerdir. Dinde yapılan tahrifatlar ve sömürü gerçek dinmiş gibi akıl dışı yöntemlerle savunularak halkın üzerinde baskı aracı olarak kullanılmıştır. Buna mukabil aklı vahyin yerine koyan deistler tahrif edilmiş vahyi reddettikleri gibi gerçek vahyi de reddederek kendilerini en önemli bilgi kaynağı olan vahiyden yoksun bırakmışlardır. Onları bu yola sevk eden birçok faktör mevcuttur. Bunların en önemlisi bilim ve teknolojinin gelişmesiyle beraber zenginleşen toplumların seküler bir hayat sürmesidir. Bununla beraber okullarda dini, tabi ve beşeri ilimlerin beraber okutulmaması, dindar olanların dini yorumlarını din gibi algılamaları, dindar olmayanların ise gerçek din ile sahtesini aynı kefeye koyarak bütün dinleri reddetmeleri ve aklın kendileri için yeterli olduğunu iddia etmeleri deizme götüren sebeplerin başında gelir.

Anahtar Kelimeler: Deizm, din, akıl, vahiy, sebepler

Makale Türü: Araştırma

\begin{abstract}
Revelation and wisdom are two important sources of information that Allah has provided the human beings with. As long as one doesn't convict one to the other in his/her own area, humanity will reach many achievements. The man has sometimes used one of these two sources of information against the other one. In the Middle Ages, especially the people representing Christianity have exploited the communities by manipulating the religion. The manipulations and exploitations in religion have been defended with unreasonable methods and caused pressure on people. Likewise, deists Who have put wisdom in revelation's role have deprived themselves of revelation by rejecting the manipulations to revelation and actual revelation. There are a lot of factors leading them to this way. The most important one is that with the development of technology and science, communities have led a secular life. Main reasons driving people to deism are that religious, natural and humane lessons are not taught altogether at schools, people regard religious people's religious commands as religion, people who aren't religious regard the actual religion and the fake one as the same and reject all the religions and claim that wisdom alone is enough for them.
\end{abstract}

Keywords: Deism, religion, wisdom, revelation, reasons

Paper Type: Research

\footnotetext{
${ }^{1}$ Uşak Üniversitesi, İslami İlimler Fakültesi, yasin.ulutas@usak.edu.tr. 


\section{Giriş}

Din, insanlık tarihi kadar eski ve her yönü ile insanı etkileyen çok önemli bir olgudur. Hangi toplumun tarihi incelenirse incelensin bu olgunun onları çeşitli yönlerden etkilediğini görmek mümkündür. İnsanoğlu tabiatı gereği tarihin her safhasında kendisini ve içerisinde yaşadığ 1 çevrede olup bitenleri merak edip sorgulamıştır. İnsan, özellikle açıktan gördüğü varlıkları ve olayları değil, daha çok anlayamadığı ve göremediği varlıkları, olayları ve olguları anlayabilmek için çaba sarf etmiştir. Müşahede edilmeyen metafizik konular, daha çok din olgusuna müracaatla çözümlenmeye çalışılmıştır. Ancak zamanla bilimin hızlı gelişmesiyle beraber bu algı değişerek dinin yerini daha çok bilim almıştır.

Din ve bilim, her dönemde insan hayatını etkileyen temel olgular olmuştur. Beden ve ruhtan oluşan bir varlık olarak insanın ruhuna din, bedenine ise bilim hizmet vermektedir. İnsan hem olduğu için din onun ruhuna, bilim ise bedenine hizmet etmiştir. Bu itibarla insanlık tarihini derinden etkileyen bu iki olgu, her zaman insan hayatında kendini etkili bir şekilde hissettirmiştir. Metafizik alanda vahyin, fizik alanında ise bilimin hâkim olması ve insanlığa hizmet etmesi gerekir. Bu iki olguya/alana doğru şekilde yer verildiği müddetçe bunlar insanlığa hizmet ederler. Ancak her dönemde bu denge sağlanamamıştır. Bazen ilahi dinler tahrif edilmek suretiyle bilim ile çatıştırılmış, bazen de bilim dinin yerine konularak din inkâr edilmiştir.

Batı dünyasında özellikle orta çağda bilime gerekli önem verilmediği gibi tahrif edilmiş Hıristiyanlık dini de kilise babalarının egemenliği altında bir baskı aracı olarak kullanılmıştır. XVI. yüzyıldan itibaren bilim, önemli gelişmeler göstererek eskisinden daha fazla ve kapsamlı bir şekilde insan düşüncesini ve mevcut kurumları etkilemiştir (Russel, 1996, s.11). Bu tarihten itibaren din taraftarlarıyla bilim taraftarları arasında kısmen günümüze kadar devam eden bir çatışma alanı hâsıl olmuştur. Bu çatışmanın birç̧ok yararının yanında zararları da söz konusudur. Bunun neticesinde ise dini duygular zayıflamış ve bütün dinler aynı seviyeye indirgenerek dini inkâr eden felsefi akımlar ortaya çıkmıştır.

Batı'da ortaya çıkan bu inkârcı felsefi akımlar, Rönesans, Reform ve Aydınlanma hareketleriyle beraber hızlı bir şekilde gelişen bilim, sanat, edebiyat, psikoloji, sosyoloji ve felsefe gibi ilimler toplumun hizmetine sunulmuş, öte yandan yine aynı bilimler aktif bir şekilde kullanılarak din ve argümanlarıyla mücadele edilmiştir. Sözü edilen tabi ve beşeri bilimler, maddi olarak toplumların refah düzeyini ve konforunu yükselttiği için dini inançlara karşı takınılan bu olumsuz tutuma karşı toplumda ciddi anlamda bir tepkiye yol açmamıştır. Aslında bazı felsefi akımların takındığı, her şeyi akıl ile açıklama ve ispat etme değilse inkâr etme, yok sayma tutumu genelde her zaman var olmuştur. İmam Gazâzalî’nin önemle üzerinde durduğu konuların başında bazı ünlü filozofların düştüğü bu hata gelir (Aydın, 1992, s.11). Bu dönemde meydana gelen aydınlanma hareketleriyle beraber akıl, her şeyin ölçüsü olarak kabul edilmiş, dini değerler ya tamamıyla inkâr edilmiş ya da akıl ile aynı şeyi söylemişse kabul edilmiştir. Metafizik konularda akıl yetersiz kalmış, dinlerin konu ile ilgili söyledikleri de inkâr edilmiştir (Ögcem, 2013, s.i). Özellikle Septisizm, Agnostisizm ve Nihilizm gibi felsefi akımlar, şüpheciliği, bilinmezliği ve hiçliği esas alarak dini ve dini değerleri inkâr etmişlerdir. Öte yandan Materyalizm, maddeyi her şeyin esası kabul ederek insanın, âlemi sadece deneme ve duyumlarla anladığını iddia ederek akılcı olduklarını söylemişlerdir. Dini değerleri bilgi kaynağı olarak görmedikleri için de her türlü dini düşünceyi inkâr etmişlerdir (Bolay,1990, s.162). Bu dönemde dini düşünceye büyük darbe vuran akımlardan biri de Auguste Comte'un (1798-1857) kurucusu olarak kabul edildiği Pozitivist akımdır. Bu akım, bilginin kaynağını sadece deney ve tecrübe ile sınırlandırarak bu iki olgunun dışında herhangi bir bilgi kaynağının olmadığını savunmuştur (Yeşilyurt, 2015, s.43). A. Comte, insanlık dini dediği Tanrı'nın yerine insanlığı, ermişlerin yerine de bilginleri koymak suretiyle yeni bir pozitivist dini savunmuştur (Akarsu, 1979, s.18).

Batıdaki felsefi akımlardan biri de deizmdir. Bu akım, daha önce zikrettiğimiz çağdaş felsefi akımların oluşturduğu sorgulayıcı zemini kullanarak görüşlerini yaymaya çalışmışlardır. 
Akım, temel olarak atıl bir Tanrı anlayışını kabul etmekle beraber dinlerin bütün değerlerini inkâr etmiştir. Özellikle sanayileşme, bilim ve teknolojinin gelişmesiyle beraber insan maddi olarak daha konforlu ve rahat bir hayata kavuşmuştur. Ancak bu durum insanı dünyevileştirmiş, manevi olarak insanın din ile bağları zayıflamıştır. Zamanla Tanrı'nın varlığı da dâhil, bütün dinleri inkâr eden Ateizm ve Tanrı'nın, insan ve Âlem ile olan ilişkisini inkâr eden deizm gibi akımlar toplumda yaygınlaşarak güç kazanmıştır.

\section{Deizm}

Deizm kavramı, köken olarak Latincede "Tanrı" anlamına gelen "Deus" kelimesinden türetilmiştir. Aslında deizm, Tanrıya inanmak anlamına gelir. Ancak zamanla Yunanca Tanrı anlamına gelen "Theos" kelimesinden türetilen Teizm, yaratıcı ulûhiyet anlayışını ifade etmek için kullanılmıştır. Deizm ise kendine özgü felsefi bir kimlik kazanmıştır (Aydın, 1994, s. 173). Felsefi bir akım olan Deizmi tarif etmek oldukça zordur. Zira bu akımın önde gelen temsilcileri, çeşitli anlayışlara sahip oldukları için birbirinden çok farklı görüşlere sahiptirler. Farklı olan bu görüşleri tek bir grupta toplayarak bir tanım yapmak beraberinde bütün görüşleri kapsayamama sıkıntısını getirebileceğinden dolayı birçok tanım yapılmıştır (Hefelbower, 1920, s.217). Ancak sözü edilen bu sıkıntılara rağmen bu felsefi akımı şöyle tarif etmek mümkündür.

"Tanrı'nın varlı̆̆ını, birliğini ve âlemin ilk sebebi olduğunu kabul etmekle beraber salt akla dayalı doğal bir din anlaylşı çerçevesinde nübüvveti ve vahyi inkâr eden felsefi bir akım olarak tarif edilebilir" (Erdem, 1994, s.109).

Deizmin savunduğu düşünceyi, tarihi süreç içerisinde farklı kültürlerde çeşitli şekillerde görmek mümkündür. Bu düşüncenin kökleri, ilk çağ tabiatçı filozoflara kadar geriye gider. Sistematik Yunan felsefesinin kurucu filozoflarından biri olan Aristoteles'in (384-322) âlem hakkındaki düşüncesinin, deizm düşüncesine kaynaklık ettiği söylenebilir. Aristoteles, kendisi salt form olan ve hareket etmeyen ancak bütün hareket eden varlıkların ilk hareket ettiricisi olan bir ilkenin var olduğunu söyler. Ona göre ilk hareket ettirici veya salt form, ezeli ve ebedidir, değişmez, hareket etmez, kendi başınadır, diğer varlıkların tümünden ayrıdır, cisim de değildir. Ancak yine de bütün varlığın oluş nedenidir. Sözü edilen ilk hareket ettirici, yetkin bir varlık olduğu için her türlü imkân ondan gerçekleşmiş̧ir. Varlıkların en yücesidir. İşte bu ilk hareket ettirici tanrıdır. Ancak bu Tanrı, hiçbir şey istemediği gibi hiçbir şey yapmaz, evrendeki hiçbir varlığı etkilemez. Kâinatta olup biten her türlü hareket ve oluş, maddenin bu ilk hareket ettiriciyi özlemesiyle meydana gelir (Gökberk,1974, s. 91-92).

Aristoteles'in anlattığı Tanrı, ilahi dinlerdeki her şeyin yaratıcısı olan faal Tanrı değil, sadece ilk muharrik olan bir Tanrı anlayışıdır. Bu nedenle Aristoteles'in vasıflandırdığ 1 Tanrı'nın müdahaleci olmaması gayet doğaldır. Ancak Aristoteles'in bu ilk hareket ettirici Tanrı anlayışının, Rönesans dönemindeki Aristotelesçilere ilham kaynağı olduğunu söyleyebiliriz. Deizm' in iki ana esası vardır. Bunlardan biri hiçbir şeye karışmayan bir Tanrı anlayışı, diğeri de aklı ve bilimi her şeyin ölçüsü olarak kabul etmesidir (Aydın, 1994, s.173).

Deizm, tevhid dininin bozulması neticesinde başka kültürlerde ortaya çıkan bir akımdır (Okumuş, 2017, s.176). İslam dünyasında da zaman zaman bütün yönleriyle olmasa da bazı yönleriyle Deizme benzer akımlar mevcut olmuştur. Özellikle bazı ilhad hareketlerini, bu çerçevede değerlendirmek mümkündür. Bu tür hareketler tarihi süreç içerisinde yeryüzünün çeşitli bölgelerinde farklı adlar altında ortaya çıkmıştır. Deizmi de bir ilhad hareketi olarak kabul etmek mümkündür. Bu bağlamda İslam düşünce tarihine baktığımızda bu akıma benzer ilhad hareketlerinin H. II. ve IV. asırlarda İslam dünyasında yaygın olarak ortaya çıktıklarını görürüz. Batı dünyasında ilhad hareketleri daha çok ateizm formatında kendini gösterirken, İslam dünyasında daha çok vahyi ve nübüvveti inkâr olarak ortaya çıkmıştır. İslam dünyasındaki Mülhidler de deistlere benzer görüşleri savunmuşlardır. Bunların ortak sloganı, "Peygamberler ve nübüvvet öldü” ş̧eklinde olmuştur (Bedevi, 1993, s.7-8). Bu ilhad hareketleri, eski Fars kültürünün üstünlügünü savunmak suretiyle İslam'ın Arapların milli dinleri olduğunu iddia etmiş̧lerdir. Bu iddialarla İslam dinini zayıflatmaya çalışırken, öte yandan entelektüel bir 
mantıkla Maniheist ve Mazdekçi inançları da yaymayı ihmal etmemişlerdir (Kutluer, 2000, s.93). İslam bilginleri, nübüvvet fikrini inkâr eden ilhad hareketlerine karşı, ilmi düzeyde mücadele etmişler. İlmi düzeyde bu akımlarla mücadele, özellikle kelamcılar ve hadisçiler üzerinde yürütülmüştür. Kelamcilar hem akli hem de nakli delillerle, hadisçiler ise daha çok nakli delillerle mücadele etmişlerdir. Öyle ki devlet tarafından bazı kelamcılar görevlendirilmek sureti ile bunlara reddiyeler yazdırılmıştır. Örneğin aşırı bir mülhid olan Beşşâr b. Bürd'ün şiirleri için Vâsıl b. Atâ şöyle der: "Bu kör mülhidin kelimeleri Şeytan'ın en saptırıcı ve aldatıcı ipleridir" (Kutluer, 2000, s.94). Yine bir mülhid olan Ebû İsa Verrâk'1n (ö.247/861) nübüvveti ve mucizeleri inkâr etmesi karşısında Mâtûrî̀î’nin onun fikirlerinin yanlışlığını ortaya koymak için, reddiye yazmasına neden olmuştur (Mâtüridî, 2002, S. 284-294). Grek felsefesi ile tabiat bilimlerini eksen alan, Ebû'l-Hüseyn Ahmed b. Yahya er-Ravendi, (ö.245) Ebû Bekir Muhammed b. Zekeriya er-Râzî (ö.313/925) gibi bazı felsefeciler ve Maniheist gruplar, İslam düşüncesindeki nübüvveti ve onun ispatında bir delil olarak kabul edilen mucizeleri kabul etmemişlerdir (Tayland,1994, s. 271). Abdurrahman Bedevi'nin bildirdiğine göre Ravendî, mucize konusundaki görüşlerini sanki Berahime'nin görüşleri imiş gibi "Kitabü’z-zümrüt” de belirtmiş̧tir. Ona göre mucizeler, hileden başka bir şey değildir. Aynı zamanda Kur'an-1 Kerim'in de mucize olamayacağını savunarak Kur'an'daki belagatin, Arap olmayanlar için bir anlam ifade etmediğini iddia etmiştir (Bedevi, 1993, s.121-130).

İmam Mâtûrî̀î, bu görüşlerin benzerlerini Ravendî’nin hocası olan Ebû İsa Verrâk'a nisbet etmiştir (Mâtüridî, 2002, s. 284). Ebû Bekir er-Râzî de Berahime'nin görüşlerini savunmuştur. Ona göre peygamberlerin getirdiği bilgiler, birbirleri ile çeliştiği için reddedilmesi gerekir. Bu gerekçe ile sadece İslam'daki nübüvvet anlayışını değil, bilakis bütün dinlerdeki nübüvvet anlayışlarını reddeden (Ülgen, 1967, s. 21). er-Râzî, Kur'an'ın belâăât, fesâhât ve içerik bakımlarından mucize olmasını da kabul etmez. Ona göre Kur'an'daki ifadelere benzer birçok ifade mevcuttur. Ayrıca insanların aydınlatılma görevi, peygamberler tarafından değil, filozoflar tarafindan yapılması gerektiğini de savunmuştur (Tayland, 1994, s.71-72). Onu bu şekilde düşünmeye sevk eden şey, muhtemelen vahyi bilgi kaynağı olarak kabul etmemesidir.

Deizm özellikle XVII. ve XVIII. yüzylllarda Avrupa'da en güçlü dönemlerini yaşamıştır. Deizm kelimesini ilk olarak Kalvinci ilahiyatçı Pierre Viret (ö.978/1571), deistleri teistlerden ayırmak için "Instruction Chrestienne" (1563) adlı eserinde kullanmıştır. Ona göre deistler, Allah'a inanmakla beraber, Hz. İsa ve öğretilerini inkâr etmişlerdir (Wood, 2011, s. 327-347). Deizmin ilk kurucularından biri olarak kabul edilen Lord Herbert'in (ö.1648) Tanrı'ya ve ahiret hayatına inanmakla beraber ilahi metinler hakkında önemli şüpheleri vardır. Ilk kez Deist olduğunu söyleyen kişinin Charles Blount (ö.1563) olduğu, ayrıca vefatından sonra yayınlanan "A Summary Account of the Deist Religion" adli eseri, deizmin yay1lmasina önemli katkılar sunmuştur (Zavalsız-Şahin, 2018, s.570). XVII. yüzyılın ikinci yarısına kadar deizmin, bir felsefi akım olarak şekillendiğini söylemek mümkün değildir. Bu kavram XVII. yüzyılın sonlarına doğru Pierre Bayle'nin (ö.1706) yazdığı sözlükte kullanılması bu kelimenin geniş bir çerçevede yaygınlaşmasına yol açmıştır. XVII. yüzyılda deist olarak bilinen Viscount Bolingbroke, John Toland, Matthew Tindal, Antony Collins, Erasmus Darvin, Diderot, Tohmas Paine ve Alberto Radicati gibi kişileri zikretmek mümkündür (Köktaş, 2017, s.150-152).

Avrupa'da meydana gelen Rönesans ve Reform hareketleri, birçok felsefi akım tarafından aydınlanma döneminin başlangıcı olarak kabul edilmiştir. Bazı aydınlar da Deizmi, bu dönemin dini olarak görmüşlerdir. Nitekim Marx Weber, Comte gibi sosyolog ve felsefeciler aydınlanmayı doğal din karşıtı veya dinin aşılması şeklinde algılamışlardır. Meşhur deistlerden biri olan Voltaire ise dinsel inancın kamusal alandan çıkarılması gerektiğini ifade etmiştir. Paul Hazard'a göre bu dönemin amacı, Hıristiyanlığı sanık sandalyesine oturtmak, mümkünse dini, tümüyle yaşamdan soyutlamak olduğunu ifade eder (Köktaş, 2017, s.144). Aslında Deizm, XVII-XVIII. yüzyıllarda İngiltere ve Fransa'da dini, özellikle de Hıristiyanlığı doğrulama, akılvahiy uyumunu savunma girişimi olarak ortaya çıkmasına rağmen, dönemin algısına ters düşen, olağanüstü olan her türlü inancı inkâr şekline evirilmiştir. Zamanla vahyin gereksiz, aklın ise 
ölçü, din ve ahlakın doğal olgular olduğu ve bunun da tabiatta bulunduğunu savunmuşlardır (Ögcem, 2013, s.108).

\section{Deizm Anlayışları}

Günümüzdeki deistleri bir tanım adı altında tarif etmek mümkün olsa da geçmişte bu felsefi akıma mensup olanların aynı anlayışta olduğunu söylemek mümkün değildir. Onlar kendi içlerinde Tanrı, âlem, vahiy, nübüvvet ve ahlak gibi birçok konuda ihtilaf etmişlerdir. Deistler çok dağınık düşüncelere sahip oldukları için sahip oldukları anlayışları tek bir ad altında tarif etmek oldukça zordur. Bu farklı anlayışları göz önünde bulundurarak ve aynı zamanda Deizme eleştirel olarak yaklaşan Samuel Clarke (ö.1141/1729) A Demonstration of the Being and Attribut es of God and Other Writing adlı eserinde deistlerin dört ayrı anlayışa sahip olduğunu belirtir. Şaban Ali Düzgün, S. Clarke'nın bahsettiği deist anlayışları şöyle gruplandırır.

1) Bazı deistler, başlangıcı ve sonu olmayan, aynı zamanda iradeli ve hür bir varlık olarak âlemi en güzel şekilde yaratan ancak âlemde meydana gelen olayların hiç biriyle uğraşmayan, atıl bir Tanrı inancina sahiptirler.

2) Diğer bir grup da Tanrı'nın âlemle ilgilendiğini, müdahale ettiğini ancak bu müdahalesinde ahlaka yer vermediğini iddia etmişlerdir.

3) Başka bir deist grup ise Tanrı'nın ahlaki sıfatlara sahip olduğunu kabul etmekle beraber ahiret inancının ve ahlaki ilkelerinin Tanrı ile insan arasında bir işlevselliğe sahip olmadığını iddia eder.

4) Bazı deistler de doğru olan dini ve ahlaki öğretileri kabul etmekle beraber bütün bunların vahiy ile sağlanabileceğini ancak bunun sadece Hıristiyan vahiy ile sağlanamayacağını iddia ederler.

5) Diğer bir grup ise aklın ve nübüvvetin tespit ettiği hakikatlere ihtiyaç olduğunu ancak bu hakikatlerin aklın süzgecinden geçerek onaylanmaları şartıyla geçerli olabileceğini söylemişler (Düzgün, 2017, s. 7-9).

Buna göre Deistler tarihi süreçte içinde yaşadıkları şartların etkisiyle farklı anlayışları savunmuşlardır. Bu anlayışları kısaca şöyle ifade etmek mümkündür.

Bazıları Tanrı'nın ahlaki bir varlık olduğunu, âleme lütuf ve merhametle baktığını ancak müdahale etmediğini savunarak mucize türü olağanüstü olayların mümkün olmadığını iddia etmişlerdir. Bazıları da Tanrı'nın insanı mükellef kıldığını, insanın ona karşı bazı sorumluluklarının olduğunu kabul ederek, ahiret hayatında mükâfat ve cezanın olduğunu savunmuşlardır. Ancak birçok kişi, bu düşünceyi savunanları deist değil, teist olarak kabul etmişler. Hıristiyan deist olarak isimlendirilen bir grup da Hıristiyanlıktaki esrarengizliği kaldırmak ve mucizelere gömülü bir din anlayışını aklileştirme çabası içine girmiştir (Aydın, 1994, s.174-175). Deistler bazen Hristiyanlığı, bazen de geleneksel bütün dinleri, inkâr ederek aklın ilahlaştırıldığı doğal bir din anlayışını savunmuşlardır (Öztaş, 2006, s. 3).

\section{Deizme Götüren Sebepler}

Toplumu yönlendiren ve dönüştüren sosyal olayların birçok farklı yönleri ve nedenleri vardır. Bunlar çağa ve bölgesel faktörlere göre farklılık arz eder. Deizm ve ateizm gibi çağdaş fikir akımların altyapısını besleyen fikirleri, ilk çağdan itibaren çeşitli bölgelerde farklı adlar altında görmek mümkündür. Ancak dinler açısından ilhad olarak görülen bu fikir ve hareketler, tarihi süreçte genellikle marjinal olarak varlıklarını sürdürürken, toplumda yayılma zeminini bulduklarında toplumun bir kesimini bazen kuvvetli, bazen de daha zayıf etkilediklerini görmekteyiz.

Deizm, ateizm ve benzeri çağdaş fikir akımlarını da sadece bir dine karşı değil, bütün dinlere karşı bir ilhad hareketi olarak görmek mümkündür. Bu ilhad hareketlerinin adları farklı olsa da ortak olarak savundukları şey, Allah'ın peygamberler aracılığıyla gönderdiği dinin gerekli olmadığı yönündedir. Bunun yerine insanda doğal olarak bulunan başta akı1 olmak üzere 
diğer doğal kabiliyetlerinin yeterli olduğunu savunarak vahiy edilen dinin yerine, insanın tabiatında bulunan yeteneklerle ortaya koyduğu doğal bir din anlayışını savunmuşlardır. Böyle bir din anlayışı ise ya bütün Tanrıları inkâr eden ya da tabiata karışmayan, insanlara müdahale etmeyen ve onlardan hiçbir şey istemeyen atıl bir Tanrı anlayışına götürmüştür. Deizm düşüncesinin farklı toplumlarda yayılma zemini bulmasının birçok farklı nedeni olmakla beraber, bu nedenlerin karakter itibariyle birbirlerinden çokta farklı olmadığını söylemek mümkündür. Bu sebeplerin bir kısmı Müslümanların, bir kısm1 da batılı toplumların ürettiği teoloji ve diğer birçok yapısal sorunlardan kaynaklandığını söylemek mümkündür. Sözü edilen bu nedenleri genel olarak şöyle dile getirmek mümkündür.

\subsection{Batı Kaynakı Sebepler}

Aydınlanma döneminde Avrupa'da Deizm, Ateizm, Pozitivizm, Materyalizm, Nihlizm ve Agnostizm gibi fikir akımlarının doğup gelişmesi, yaygınlaşması ve taraftar bulmasının birçok bölgesel veya genel nedenleri vardır. Yapılan araştırmalar bu tür fikri akımların orta çağda hâkim olan skolastik felsefeye reaksiyon olarak doğduklarını ortaya koymuştur. Özellikle Deizm akımının batıda gelişmesine neden olan faktörlerin başında, tahrif edilmiş Hıristiyan ilahiyatı gelir. Bu teolojinin üçlü ilah anlayışı, insanın doğuştan günahkâr olması, Hz. İsa'nın insanları bu doğuştan gelen günahtan arındırmak için yeryüzüne geldiği ve ilahi bir tabiata sahip olduğu şeklindeki inançlarının rasyonel olarak savunulamaması insanların Hıristiyan ilahiyatını sorgulamalarına yol açmıştır. Kilise akıl ile çelişen bu inançlarını akli olarak kabul ettiremediğinden dolayı bu inançlarını topluma zorla dayatması, insanların deney ve gözleme dayalı bilgiye önem vermesine, bilgi felsefesinin değişmesine, din-bilim çatışmasına yol açmıştır. Bütün bu değişimler karşısında Kilisenin kendisini 1slah edememesi ve farklı fikirleri zor kullanarak bastırmaya çalışması, geçmişte var olan deist fikirlerin yeşermesine ve toplum nezdinde yaygınlaşmasına yol açmıştır (Coşkun, 2017, s. 45).

Hıristiyan dininde yapılan tahrifat, Deizme götüren sebepler arasında sayılmışsa da bu tahrifatın deizm ile doğrudan bir bağlantısı yoktur. Çünkü bu tahrifat ile Deizmin çıkışı aynı döneme denk gelmez. Aziz Pavlus ile başlayan bu tahrifat ve akıl ile savunulması mümkün olmayan inanç ilkeleri, Hristiyan Avrupa toplumunda asırlarca ciddi bir tepki görmeden varlığını sürdürmüştür. Kısmen sürdürmeye de devam etmektedir. Ancak XVI. yüzyıldan itibaren bilimsel olarak birçok keşfin yapılması, Rönesans ve Reform hareketleriyle beraber dini ilkeler sorgulanmış bunun neticesinde otoriteleri sarsılan kilise ve din adamları, bilim adamları ve öne sürülen sorgulayıcı fikirlere karşı şiddetli bir şekilde mücadele ederek birçok bilim adamını cezalandırmışlardır. Kilisenin bilim insanlarına karşı uyguladığı şiddet politikası, bir türlü bitmeyen din savaşları gibi nedenler din-bilim çatışmasına zemin hazırladığ gibi hayatın her yönünü ilgilendiren her türlü dini düşünceyi reddeden veya en azından eleştirel bakan yeni akılcı bir hayat anlayışının doğmasına öncülük etmiştir. Aydınlanma olarak adlandırılan dönemde edebiyat, sanat gibi çeşitli alanlarda salt aklı esas alan birçok felsefi akım ortaya çıkmıştır. Bu felsefi akımların çoğu deist düşünceye hizmet ettiğini söyleyebiliriz. Nitekim bu akımlardan Hümanizm, Tanrı'ya karşı insanı merkeze alan, karar verme süreçleriyle ilgili hayatın her safhasındaki ahlakın temeli olan her türlü dini ilkeleri ret etmek suretiyle akıl, bilim ve adaleti benimsediğini savunur (Cevizci, 2012, s. 217). Yine dini düşüncenin tamamiyla insan hayatında çıkarılmasını zorunlu görerek deist düşüncenin yayılmasına katkı sağlayan felsefi akımlardan biri de Sekülarizmdir. Bu akımın hem nesnel hem de öznel yönleri vardır. Öznel boyutu hayattaki olguların, her türlü olgunun anlaşılmasında dini duygu ve düşüncelerin çıkarılmasını savunmuştur. Yine nesnel boyutu ise dini kurum ve uygulamaların hayatın bütün unsurlarından çıkarılması gerektiğini savunmuştur (Cevizci, 2012, s. 389).

Aydınlanma dönemi, David Martin tarafından şöyle karikatürize edilmiştir. "Tanrı öldü. Bu nedenle laiklik yeşermelidir ve bundan dolayı laiklik vazgeçilmezdir" (Chadwick, 2004, s. 7). XIX. yüzy1lda bu düşünceye hizmet eden birçok ulus devleti kurularak her türlü dini prensipler eğitim, sanat, hukuk, siyaset vb. tüm alanlardan tamamıyla çıkarılmıştır. Özellikle batıda ortaya çıkan bu felsefi fikir akımları, bir ideoloji haline getirilerek dinin karşısına 
konumlandırılmak suretiyle bir yaşam biçimi olarak takdim edilmiştir. Rönesansı kendisine başlangıç kabul eden, aydınlanma ile kendine hayat bulan felsefi akımlar, bu dönemi tanımlayan özelliklerin tümünü moderinite kavramı ile tanımlamışlardır. Bu kavramın mucidi olan Hegel, düşünce yapısında dine yer vermeyen dinden bağımsız olan her türlü düşünceyi modern olarak kabul eder (Cevizci, 2012, s. 305-306).

Başta Avrupa'da tahrif edilmiş olan Hıristiyanlık ve onu temsil eden kiliseye karşı tepki olarak ortaya çıkan bu düşünceler, özellikle kitle iletişim araçlarının çeşitlenmesi ve çoğalmasıyla dünyanın her tarafında geniş halk yığınlarını etkilemiştir. Her türlü dini düşünceden arındırılan düşünceler, çağdaş ve modern gösterilerek yaygınlaştırılmaya çalışılmış yaşamlarında dini değerlere yer verenler, zaman zaman yobaz, gerici gibi aşağılayıcı argümanlarla en hafifiyle toplum dışı ilan edilmiştir. Yaşamında dini değerlere yer vermeyen insanların çoğu, kendisini modern veya çağdaş görürken kendilerini Deist olarak görmeye bilirler. Ancak sonuç itibariyle bu şekilde düşünenlerde kendi hayatlarına müdahele etmeyen bir Tanrı inancını kabul etmiş olurlar.

XVI. yüzyıldan itibaren batıda psikoloji, sosyoloji, felsefe ve edebiyat gibi birçok alanda yazılan eserlerin büyük çoğunluğu özelde Hristiyanlık genelde bütün dinlerin ilke ve değerlerini ya doğrudan inkâr etmişlerdir ya da bütün dinler ile alay edici bir üslup kullanarak aşağılamışlardır. Örneğin Voltaire'nin yazdığı "Felsefe Sözlüğü̈" adlı kitap, bir felsefe sözlügünden ziyade özelde Hiristiyan dinine ait inanç ilkelerini genelde ise tüm dinleri eleştiren bir eleştiri kitabı olarak değerlendirmek mümkündür. Nitekim bütün dinleri birazda, alaylı bir biçimde şöyle eleştirir: "Zamanımızın 1763 yılının 18 Şubatında, güneş balık burcuna girerken, bütün dostlarımın bildiği gibi, gökyüzüne götürüldüm. Ama üzerine bindiğim ne Muhammed'in kısră̆ı Burak'dl, ne de arabam Elie'nin alevler içindeki savaş arabası; bu geziyi ne Siamlı Sammonokodom'un filinin, ne İngiltere'nin efendisi Ermiş George'un atının, ne Ermiş Amonius'un domuzunun sırtında yaptım: bütün saflığımla itiraf edeyim ki bu geziyi nasıl yaptığımın ben de farkında değilim" (Voltaire, 1995, s. 297). Din adına ortaya atılan bütün inanç ve düşünceler, aydınlanma dönemi yazarlarınca yazılan eserlerde sert bir şekilde eleştirilmiş, bazen de alay edilmiştir. Yapılan bu menfi çalışmalar, önce batılı toplumlarda etkisini göstererek, toplumun büyük bir kesiminin din ile arasına belli mesafeler koymasına ve din adına belirtilen bütün değerler, inkâr edilerek hayatın her alanından çıkarılmasına yol açmıştır. Bilim ve teknolojinin gelişmesi ile beraber bu eserler, tercümeler yolu ile birçok dile çevrilerek bu eleştirel düşüncelerin batı dışındaki ülkelerde de yayılmasına zemin hazırlamıştır. Ancak şunu belirtmekte de fayda vardır. Aydınlanma dönemi ile başlanan eleştirel bakış, ilahi dinlere sonradan sokulan veya tahrif edilen inançların eleştirilmesine katkı sağlamıştır. Aslında Aydınlanma döneminin belki de en önemli sonucu olan eleştirel düşünce, vahiy teolojisine diğer bir deyimle Kur'an kelamı düşüncesine olumlu katk1 sunduğunu söyleyebiliriz. (Evkuran, 2014, s.40). Ancak teoloji konusunda yapılan eleştirel düşünce, İslam dünyasında ciddi dirençlerle karşılaşmıştır. Bu direncin birçok nedeni olmakla birlikte şunu belirtmekte fayda vardır. Din ve onun yorumu olan teolojiyi kesin sinırlarla ayıramayan, kendi yorumunu din olarak gören her türlü zihniyet, kendi ürettikleri teolojiye yönelik yapılan her türlü eleştiriyi dine yapılmış bir saldırı olarak kabul etmek suretiyle karşı çıkmıştır. Bu şekilde düşünenlerin nezdinde en tehlikeli insanlar okuyanlar, anlayanlar, sorgulayanlar ve farklı bilgi öğretenlerdir. Onlara göre en iyi insan teslim olan ve kendilerine verilen her görevi itiraz etmeden yapandır. Örneğin bu insanlar nezdinde Kur'an-1 Kerim'in anlaşılmadan okunmasında bir sorun yoktur. Ancak okunan Kur'an'ın anlaşılması için gösterilen çabalara şiddetle karşı çıkarlar. Kur'an-1 anlama ve yorumlama yetkisinin sadece kendilerinde olduğunu düşünürler. Kur'an-1 anlamayı engelleyen zihniyet, kitle iletişim araçlarının bir köy haline getirdiği bir dünyada, gençlerin ne zihin ne de duygu dünyasını kontrol etmeleri mümkün olmadığı söylenebilir.

Aydınlanma felsefesinin batılı temsilcileri, birçok doğmadan meydana gelen tahrife uğramış Hristiyanlığı inceledikçe, ondaki tutarsızlık ve çelişkileri görmeleri neticesinde akılcı doğal bir din olan Deizme dört elle sarıldıklarını söyleyebiliriz. Daha önce belirttiğimiz 
nedenlerden dolayı deistlerin Hristiyan ilahiyatı karşısındaki bu tutumu anlaşılabilir bir tutum olmakla beraber onların temel hatası, bütün ilahi dinleri aynı seviyede görüp inkâr etmeleridir. Hâlbuki Hristiyanlık için söylenenleri, İslam dini için de aynı şekilde söylemek mümkün değildir. Bu nedenle şunu söylemek mümkündür. Doğru bir İslam din eğitim alan bir insanın deizmi seçmesi çok zayıf bir ihtimal olarak görmek mümkündür.

Hz. Peygamber Allah'tan aldığ 1 vahyi istenildiği gibi insanlara anlatmıştır. Ancak ondan sonra bu görevi alan insanlar zamanla yorumlarını dinin yerine koymaya çalıştılar. Kendi yorumunu doğru, diğer yorumları batıl olarak görmeye başladılar ve birbirleriyle mücadele etmeye başladılar. Çünkü peşinde oldukları hakikat tekti. Kendi teolojisinin doğruluğunu diğerlerinin yanlışlığını ispat etme üzerinde kurmaya çalıştılar. Bu durum sağlıklı bilgi üretmeyi engellemiş onları bir iç mücadeleye sürüklemiştir. Bu geleneğin hala devam ettiğini söylemek mümkündür. Özellikle Allah'ın mutlak hâkim olduğu fikrini, esas alan anlayışlar ile vahdet-i vücut teorisini benimseyenler tabiata ve insana gereken değeri vermemişler. Nedenselliği Allah'ın iradesini sınırlandırır endişesiyle deizme götüreceğini iddia etmişlerdir. (Evkuran, 2014, s.38-46). Hâlbuki düşünce merkezine Allah'1 koymak tabiat ve insana değer vermemeyi gerektirmez. İnsana ve tabiata değer vermek Allah'ın emridir. Peygamberin yaptığı görevi teoloji üreten ekoller yapmaktadirlar. Bunlar hala mucizeler ve mehdiler beklemektedirler. Davalarını şahıslar üzerinden yürütmektedirler. İslam dininin ortaya koyduğu evrensel temel ilkeleri görmezden gelmektedirler. Böyle bir ortamda gücünü doğruluğundan değil, güçlü propagandadan alan çağdaş batının fikir akımları, gençlere daha cazip geldiğini söylemek mümkündür.

\subsection{Müslüman Toplumların Yapısal Sorunlarından Kaynaklanan Sebepler}

Erken dönemden itibaren Müslümanlar arasında meydana gelen siyasi ve dini ihtilaflar, Cebriye ekolünün doğmasına neden olmuştur. Bu ekol, insanın işlediği fiillerin insanla bir ilgisinin bulunmadığını belirterek âlemdeki bütün fiillerin Allah'ın ezeli iradesinin bir tezahürü olarak meydana geldiğini savunmuştur (Şehristani, 2011, s. 85-86). Emevî sultanları bu cebri anlayışı istismar ederek yaptıkları fiillerin Allah'ın takdiri ile olduğunu iddia ederek, kendi fiillerinin sorumluluğunu Allah'a nispet etmeye çalışmışlardır (Kubat, 2014, s.186). İnsana kendi davranışlarının sorumluluğunu yüklemeyen dini anlayış, özellikle kuvvetli olan kişiye istediği gibi hareket etmeyi, sorumluluğunu da başkasına atmayı öğretir. Böyle bir anlayış, kişiyi kendi arzularıyla eylem yamaya ve sorumluluktan kaçınmaya sürükleyebilir. Bu anlayışa göre zalimde mazlumda kendi kaderini yaşar. Buna müdahale etmeye gerek yoktur. Çünkü takdiri ilahiyi değiştirmeye kimsenin gücü yetmez. Her ne kadar cebri ve deist anlayışların çıkış1 noktaları tamamıyla farklı olsa da sonuç itibari ile aynı kapıya çıktıklarını söyleyebiliriz. Çünkü biri nübüvveti inkâr ederek ilahi iradeyi hayatından çıkararak yaşamaya devam etmekte diğeri de yaptığı davranışın sorumluluğunu Allah'a atmak suretiyle istediği gibi yaşamaktadır.

İmanı ikrardan ibaret gören Mürcie, imanın hayattaki yansıması olan amele gereken önemi vermemiştir (Bağdâdi, 2014, s. 148). İmanı bilgi olarak kabul eden Mürcie, kötü davranışların insanın imanına zarar vermeyeceğini savunmuştur. İnsan fiillerinin imanı etkilemeyeceğini savunan bu ekol, puta secde etmenin küfre delâlet ettiğini ancak küfür olmadığını savunabilmiştir (Bağdâdi, 2014, s.150). Onlar, iman amel ilişkisini Şehristânî'nin deyimi ile şöyle ifade etmişlerdir: "Küfürle beraber taatın bir faydası bulunmadığı gibi, imanla beraber mâsiyet de zarar vermez" (Şehristani, 2011, s. 129). Şehristânî'nin formüle ettiği bu anlayışa göre kişi iman ettikten sonra istediği fiili yapabilir. İmanı hiçbir şekilde olumsuz anlamda ekilemez. Bu düşünce, kişiyi imanın gereği olarak yaşamaya değil, kendi arzularına uygun yaşamaya sevk eder. Amelsiz bir iman anlayışı, pratikte kişiyi atıl bir Tanrı anlayışına götürdüğünü söylemek mümkündür.

Hicri ikinci asırdan itibaren felsefenin İslam kültürüne girmesi ile beraber bazı felsefeciler tabiat felsefesine dayalı bir tabii veya diğer bir deyimle deistik bir teoloji inşa etmeye çalıştıklarını söylemek mümkündür. Bu felsefeciler tabiat felsefesi yaptıkları için değil, 
daha çok ilahiyat ile ilgili düşüncelerini tabiat felsefesinden aldıkları için Tabiîyyûn olarak adlandırılıp eleştirilmişlerdir. Örneğin Serahsî (ö.483/899) Mutezile ekolünün etkisinde yetişmiş, mutezilenin akılcı tutumunu daha ileri bir safhaya taşıarak dehriler gibi bilgininin sadece duyularla elde edilebileceğini savunmuş, nübüvveti inkâr ederek peygamberleri şarlatan olarak görmüştür. Nitekim Ebû Bekir Muhammed İbn Zekeriya er-Râzî her ne kadar kavramsal olarak deist olduğunu söylememişse de, muhteva olarak sahip olduğu anlayış ile batılı deistlerin savunduğu anlayış arasında çok büyük benzerlikler olduğu iddia edilmiştir (Bayrakdar, 1988, s. 93-97). Bu iddiayı daha çok klasik mezhepler tarihi yazarları, dillendirerek Ebû Bekir Muhammed er-Râzî'nin mülhid olduğunu iddia etmişlerdir. (Ebû Hâtim, 1397, s.27). Ancak bazı araştırmacılar, Râzî̀yi mülhit olarak değerlendirenlerin genelde Şia mezhebine mensup olduklarını, Râzî'nin onlara karşı reddiyeler yazdığını, ayrıca konu ile ilgili verdikleri bilgilerden bazı tutarsızlıklarının olduğunu belirterek, verilen bu bilgilerin objektif olmadığını söylemişlerdir ( Akyüz, 2017, s.21-22). Ebû Bekir er-Râzî'nin telif ettiği eserlerin çoğu günümüze ulaşmamıştır. Mevcut eserlerinden yola çıkarak onun mülhid olup olmadığını tespit etmek mümkün değildir. Üçüncü şahıslar tarafından verilen bilgiler şüphe içermekle beraber genel kanı nübüvveti kabul etmediği yönünde olduğu söylenebilir (Bayrakdar, 1988, s. 97;Taylan, 1994, s.73-74).

Özellikle İslam dünyasında deizmin hayat bulmasının diğer bir nedeni de tek yönlü eğitim ve öğretim sistemleri ile ilgilidir. İslam dünyasından uzun bir süre okullarda sadece dini ilimlere önem verilerek okutulmuştur. Özellikle XVIII. Yüzyıldan itibaren Batılı ülkelerin tabi, doğal ve beşeri ilimlerde gösterdiği başarılar İslam dünyasını batılı toplumlarla rekabet edemez hale getirmiştir. Bu eksikliği tamamlamak için İslam dünyasında da Avrupa'daki okullara benzer yeni okullar açılmak sureti ile doğal ve beşeri bilimler okutulmuştur. Bu açılan okullar ile klasik okullarda farklı müfredatlar uygulanarak yetiştirilen insanlar arasında anlayış farklılıklarına hatta birçok bölgede çatışmalara neden olmuştur. İslam dünyasında asırlarca dini bilgi üreten Medreseler, içtihat kapısı kapandı sloganıyla hareket ederek bilgi üretmeyi bırakıp, geçmiş dönemlerin şartlarında oluşturulan bilgiyi din olarak aktarmayı kendilerine görev olarak kabul ettiler. Bu zihniyetle yetişen insanlar, ortaya çıkan yeni sorunları geçmişin şartlarından oluşturulan bilgi ile çözmeye çalıştılar. Ancak zamanın ruhundan doğmayan bu bilgi ile modern dönemin sorunlarına çare olamadılar. Bu zihniyetin temel özelliği tek tip olması ve her türlü fikirsel çeşitliliği reddetmesidir. Geçmişi tümü ile reddetmeyen ancak değiş̧en şartlar ve sorunlar karşısında yeni bilgi öğretmeyi gerekli gören anlayışları dışladılar ve mücadele edilmesi gereken tehlikeli gruplar olarak kabul etiler. (Ören, 2019, s.341-349).

$\mathrm{Bu}$ çatışmalar, bir taraftan deizm gibi hayatı seküler hale getiren çağdaş inkârcı akımların yaygınlaşmasına neden olurken, eleştirel bir kültüre tahammül etmeyen, kendi teolojisini din olarak kabul eden, birçok dini hareketlerin hayat bulmasını da sağlamıştır. Bu hareketlerin bir kısmı bir tarafta Arapların örf adet gelenek ve görenekleri ile diğer taraftan birçok mistik kadim kültürü birleştirip din adına sahip çıkarken, bazıları da çağdaşlık ve ilericilik k1lıfları altında farklı kültürlere ait ruh göçü, aura, meditasyon, falcılık ve astroloji gibi ruhçu görüşlerle toplumu istediği gibi yönlendirmeye çalışmaktadırlar. Her iki kesimde olağanüstü mistik güçlere sahip olduğunu iddia ederek toplumun sorunlarını çözmeyi vadetmektedirler. Vahyi ve insanın fitri yapısını dikkate almayan, çoğulculuğu tehlike olarak gören, değişen sorunlar karşısında çağdaş bilgi öğretemeyen dini ve felsefi akımlar, satanizim ve deizim gibi tepkisel akımlara zemin hazırlamışlardır.

Günümüzde İslam dünyasında atıl bir Tanrı anlayışını kabul etmekle beraber, aklı dinin yerine koymak suretiyle bütün ilahi dinleri reddeden Deist anlayışların, daha çok dini bir eğitim görmemiş seküler bir hayatı benimseyen gençler arasında yaygın olduğunu söylemek mümkündür. Bunu, konu ile ilgili yapılan anketlerde ve deizm derneği üyelerinin özgeçmişlerinde görmek mümkündür (Zavalsı-Şahin, 2018, s. 567-599).

İslam dünyasında deizm ve benzeri görüşler taban bulmaya başlamışsa bunun dış sebepleri olduğu gibi Müslümanların kendisinden kaynaklanan nedenlerin de olduğunu gösterir. 
Bu nedenlerin başında bilgi üreten Müslüman aydınların çağın sorunlarını iyi okuyamadıklarını ve toplumun değişen dinamik yapısına uygun çözümler üretemediğini gösterir. Bilgi üreten aydınlar, insanın psikolojik ve sosyolojik yönünü dikkate alarak akıl ve vahyin ışı̆̆ında toplumu doğru bir şekilde yönlendirmelerde bulunamazlarsa, toplum her zaman hem zihinsel olarak hem de fiziksel olarak tehlikelere açık hale gelir. Bu tehlikeler geçmişte farklı kültürler den gelmiştir. $\mathrm{Bu}$ gün ise çağdaş Avrupa kültüründen gelmektedir.

Ülkemizdeki deizm derneğinin kuruluş bildirgesi dikkatlice okunduğunda sloganlaştırılan bazı ifadelerden hareketle kendi içerisinde tutarsız teolojilere ve bu teolojileri temsil eden kesimlere karşı bir tepkinin ifadesi olduğunu görmek mümkündür. Bazı ifadelerinde ise din ile teolojiyi karıştırdıklarını görüyoruz. Örneğin deistlerin slogan haline getirdiği bir iki cümle şöyledir. "Seversen çocuklar olur, savaşırsan çocuklar ölür." Başka bir slogan da şöyledir: "Tanrı için yapılan savaşlar, şeytan için yapılan savaşlardan çoktur" (Deizm Derneği Kuruluş Bildirgesi, 2020). Günümüzde İslam dünyasında yaşanan ve çok uzun süre devam eden birçok iç savaş neticesinde milyonlarca günahsız insan öldürülmektedir. İnsanlar ister istemez kördüğüm haline gelen iç savaşlar ve dini kendi çıkarları için istismar eden terör örgütlerinin bu kargaşa ortamında sergiledikleri vahşi tutumlar, özellikle din ile dini işletenleri aynı kefeye koyan bazı kesimleri, dinden uzaklaştırarak deizm ve ateizm gibi akımların kucağına ittiğini söylemek mümkündür.

Deizmi savunanlar, günümüzde yaygın olan bütün iletişim kanallarını kullanarak, sadece kendi yorumunu din olarak kabul eden, dini görünümlü terör örgütlerinin yaptıklarını olumsuz eylemlerinden istifade ederek kendi görüşlerini yaymaya çalışmaktadırlar. Örneğin deizm derneği kuruluş bildirgesinde şöyle der: "Yaratıcı sevdirir, din savaştırır. Din ötekileştirir, Tanrı birleştirir" (Deizm Derneği Kuruluş Bildirgesi, 2020) şeklindeki sloganlarla dini işletenlerin hatasını, sanki bu hatalar bütün dinlerin kendi özünden kaynaklanıyor gibi, bütün dinlerin insanları ötekileştirdiğini ve birbirleriyle savaştırdığını iddia etmiş̧lerdir.

Ülkemizdeki insanların çok büyük çoğunluğu kendisini Müslüman olarak görmesine rağmen kendisini dindar değil, seküler olarak tanımlar. Dinin kendi hayatında etkili olmadığını savunur. Bu kesimi deist olarak tanımlamak mümkün değilse de pasif deist olarak tanımlamak mümkündür (Coşkun, 2017, s. 234). Kendisini deist olarak görenlerin sayısı çok azdır. Ülkemiz için tehlikeli olanlar, kendisini deist olarak tanımlayanlar değil, daha çok kendisini Müslüman olarak görüp dini hayatlarından çıkaran insanlardır. Günümüzde İslam için tehlikeli olan deizm ve felsefesi değil, kaynağını vahiyden alan bir teolojinin insanlara sunulamamasıdır.

Erken dönemden itibaren farklı sebep ve kaygılardan doğan siyasi ve itikadi vahyin ruhuna uygun bir teoloji geliştirememişler. Hariciler insanın fitri yapısını göz ardı ederek günah işleyenleri tekfir etmişlerdir. Şia siyasi olan imamet teorisini inanç ilkesi haline getirmiş imamları peygamberin mirasçısı olarak telaki etmiştir. Diğer yandan Mürcie imanı bilgiden ibaret görerek, amele gereken önemi vermemiştir. Cebriye ise Allah'1 fâili muhtar olarak görmek suretiyle insan iradesini yok etmiş̧ir. Bu telakilere sahip akımların bir kısmı aynı ad altında varlı̆̆ını sürdürürken bazıları da farklı adlar altında çeşitli gruplar içerisinde bu zihniyetlerini devam etmektedirler. Birçok alanda farklı gruplar olduğu gibi teoloji konusunda da birbirlerine yakın grupların oluşması gayet doğaldır. Bu grupların çağın bütün birikimlerini kullanarak vahiy merkezli bir teoloji inşa etmeleri beklenirken aksine bu gruplar birbirlerini rakip görerek biri diğerini dışlamakta, batıl saymakta ve kendi varlığı için tehlikeli görmektedir. $\mathrm{Bu}$ durum başta gençler olmak üzere Müslüman toplumu inkârcı akımların tuzaklarına açık hedef haline getirmektedir.

Bugün çağın bütün imkânlarına rağmen birçok Müslüman, Kur'an-1 ya hiç okumuyor ya da okuduğu halde hiç anlamıyor. Bu nedenle de dini istismar edenlerin tuzağına daha kolay düşebiliyor. Diğer taraftan din düşmanları onların bu cehaletinden azami derecede faydalanmayı çok iyi bilmektedirler. Aslında en tehlikeli olan durum bu durumdur. 


\section{Sonuc}

İman ile inkâr veya vahiy ile akıl dünya tarihi kadar eskidir. İlk insandan beri bir dine inanan insan olduğu gibi inanmayanlar da hep var olmuştur. Her dönemde ayrı düşünceler insan tabiatı gereği ortaya atılıp tartışılmıştır. Ancak tartışılan bu fikirlerden hangisi toplumda yayılma zemini bulursa yayılmıştır. Deizm düşüncesini, aynı isim altında olmasa da fikir olarak ilk çağ filozoflarına kadar götürmek mümkündür. Lakin bu düşünce, çok uzun bir süre toplumda yayılacak bir zemin bulamamıştır. XVI. yüzyıla gelindiğinde bu düşüncenin, bazı özel ve genel sebeplerden dolayı yavaş yavaş toplumda yayılma zeminini yakaladığını söyleyebiliriz. Bu zemini yaratan birçok faktör mevcuttur. Ancak özetle şunlar söylenebilir.

İnsan fitratı farklı olduğu için olguları farklı anlamaktadır. Biri anladığı için inanmaktadır diğeri de yine farklı bir şekilde anladığı için inkâr etmektedir. Din-bilim çatışmasına zemin hazırlayan sebepler ile deizme götüren sebepler benzer sebeplerdir. Özellikle bilimin hızlı gelişmesi, sanayi devrimi ve makineleşme ile beraber toplumda etkin bir rol üstlenen bilim adamlarını, kilise ve ruhban sınıfı kendi otoritelerine karşı bir tehlike olarak görerek, birçok bilim insanını cezalandırma yoluna gitmişlerdir. Buna mukabil birçok bilim insanı da özelde Hıristiyanlığı genelde bütün dinleri aynı kefeye koyarak eleştirmişlerdir. Tarihi süreç içerisinde dini temsil edenlerin din adına gerçekleştirdikleri yanlış söylem ve uygulamalar, zamanla seküler bir anlayışın yaygınlaşmasına ve teslimiyetçi bir din algısından sorgulayıcı bir din algısına evirilmiştir. Bu anlayış, dini cemiyetin hayatından ya tümüyle çıarılmasına veya ahlaki bir alanla sınırlandırılmasına yol açmıştır. Dinin toplum hayatında yer almadığı bu dönem aydınlanma, çağdaş veya modern kelimeleriyle ifade edilerek dinin etkin olmadığ toplumun ideal toplum olduğu vurgulanmıştır. Bu uygun şartları iyi değerlendiren deistler, düşüncelerini yaymaya çalışmışlardır. Deistler kendi aralarında farklı anlayışlara sahip olmakla beraber her türlü vahyi ve nübüvvet düşüncesini inkâr ederek, tabiata müdahale etmeyen atıl bir Tanrı anlayışını kabul etmişlerdir. Aklı dinin yerine koyarak inanın doğasından kaynaklanan doğal bir din anlayışını savunmuşlardır.

Deistlerin iddia ettiği gibi, şayet nübüvvet ve vahiy olmasaydı insanlık sadece kendi doğal yetenekleriyle bugünkü medeniyet seviyesine gelebilir miydi? Bu soruya olumlu cevap vermek mümkün değildir. Zira akıl ve vahiy, Allah'ın insana bahşettiği iki bilgi kaynağıdır. Bunlardan biri eksik olursa sahip olduğu bilgi kaynaklarından birinden yoksun kalmış olur. Deistlerin iddia ettiği gibi olsaydı, insan bırakın bugün geldiği seviyeye gelmeyi belki de varlığını koruyamazdı. Allah'ın yardımı ve yönlendirmesi olmadan insanın doğal yetenekleriyle yeryüzünde yaşamanın alt yapısını oluşturup bugünkü yaşam seviyesini yakalaması pekte mümkün görünmemektedir. Zira yeryüzünde yaşayan geçmiş toplumların hayatına geriye dönük olarak baktığımızda dinin eserlerini görmek mümkündür. Bunu inkâr etmenin, kendisini inkâr etmekle eş anlamlı olduğunu söyleyebiliriz.

Sonuç olarak şunu söylemek mümkündür. Deist düşünce ile mücadele etmenin en iyi yolu Kur'an düşüncesini ve nübüvvetin gerekliliğini doğru bir şekilde anlamak ve yaygınlaştırmaktan geçer. Bu yapıldığ takdirde sonradan İslam dinine sokulan, bid'ât, hurafe ve isrâiliyâttan kurtulmuş olunduğu gibi, doğru bir dinin yaşanılması da sağlanmış olur. İlk dönemden itibaren İslam düşünce ekolleri bazı yararlı işler yapmakla beraber vahyi okumaları bütüncül değil parçacı olmuştur. Günümüzde de bu anlayış ana akım Müslümanlar arasında yaygın olarak varlığını sürdürmektedir. Kendilerine göre vahyin bir kısmını önemli görüp sembol haline getirirken, diğer kısmına ya gereken önemi ya da görmemezlikten gelmişlerdir. $\mathrm{Bu}$ durum Müslüman toplumun sağlıklı bir teoloji inşa etmesini engellemiştir. Şayet Müslüman toplumlar sağlıklı bir teoloji inşa edip birlik ve beraberliklerini sağlamak istiyorlarsa bütüncül, eleştiriyi esas alan doğal, beşeri ve dini ilimleri bir arada sağlıklı olarak okutmaları gerekir. Çözüm olarak şunu söylemek mümkündür. Allah'ın indirdiği din, aklın ışığı ile topluma doğru anlatıldığı sürece deizme götüren sebepler ortadan kaldırılmış olur. 


\section{Kaynakça}

Akyüz, T. (2017). Ebû Bekir Zekeriyyâ er-Râzî'nin felsefl görüşleri. İstanbul: Ravza Yayınları.

Akarsu, B. (1979). Çağdaş felsefe. İstanbul: Milli Eğitim Basımevi.

Aydın, M. (1994). Din felsefesi. İzmir: İzmir İlahiyat Vakfi.

Bayrakdar, M. (1988). İslam felsefesine giriş. Ankara: AÜIFYYayınları.

Bağdâdî, A. (2014). Mezhepler arasındaki farklar (Ethem Ruhi Fığlalı Çev.) Ankara: TDV Yayınlar1.

Bedevi, A. (1993). Min târihi'l- ilhad fil islam. Kahire.

Bolay, S. H. (1990). Felsefî doktrinler sözlüğü. Ankara: Akçağ Yayınları.

Cevizci, A. (2012). Felsefe sözlüğü. İstanbul: Say Yayınları.

Chadwick, O. (2004). 19. Yüzyıl Avrupalı Aklın Sekülerleşmesi (Murat T. Aslan Çev.). İstanbul: Birey Yayıncılik.

Clarke, S. (1998). A demonstration of the being and attributes of God and other writings (E.Vailati ed.), Cambridge:Cambridge University Press. doi.org/10.1017/CBO9780511583346

Coşkun, İ. (2017). Modern çağ deizminin nedenleri ve sonuçları. Din Karşıtı Çağdaş Akımlar ve Deizm Kongresi, Van Yüzüncü Yıl Üniversitesi, Van.

(DD), "Deizm Derneği Kuruluş Bildirgesi” (Erişim tarihi: 27.01.2020). www.scribd.com.

Düzgün, Ş. A. (2017). Deizm: Öncü İsimler ve Temel Doktrin. Diyanet Aylık Dergi 320 (8), 79. www.diyanet.com.tr

Erdem, H. (1994). Deizm. Türkiye Diyanet Vakfi İslam Ansiklopedisi Ankara:TDV Yayınları.

Evkuran, M. (2014). Eş'arî Kelam Sisteminin Teolojik Temelleri Üzerine Deizm Bağlamında Bir Tartışma. Uluslararası İmam Eş'arî ve Eş'arîlik Sempozyumu Bildirisi. Sirt: Beyan Yayınları.

Gökberk, M. (1974). Felsefe Tarihi. İstanbul: Bilgi Yayınevi.

Hefelbover, S.G. (2020). Dcism Historically Defined. The American Journal of Theology, https://www.jstor.org/stable/3155405.

Köktaş, M. (2017). Aydınlanma, Hıristiyanlık ve Deizm. Anadolu Üniversitesi Sosyal Bilimler Dergisi, 17(1), 143-157. doi: org/10.18037/ausbd.415672

Kubat, M. (2014). İslam mezhepleri tarihi. Konya: Kitap Dünyası Yayınları.

Kutluer, İ. (2000). İlhad. Türkiye diyanet vakfi islam ansiklopedisi (22), 93-96 İstanbul: TDV Yayınları.

Mâtüridî, M. (2002). Kitâbü't-Tevhid (Bekir Topaloğlu Çev.) İstanbul: İsam Yayınları.

Râzî, E. Hatim (1977). A'lâmü'n-nübüvve. Tahran: İran Felsefe Akademisi.

Russell, B. (1996). Din ile Bilim (Akşit Göktürk Çev.). İstanbul: Say Yayınları.

Okumuş, N. K. (2017). Yetersiz bakiye: Deizm'in tanrı tasavvuru ya da Sünettullah yasaları ve deizm ilişkisi üzerine bazı tespitler. Din Karşıtı Çağdaş Akımlar ve Deizm Kongresi, Van Yüzüncü Y1l Üniversitesi, Van. 
Ögcem, E. (2013). Ateizmden Deizme Antony Flew.(Yayınlanmamış doktora tezi). MarmaraÜniversitesi, İstanbul.

Ören, M. F. (2019). Türkiye'de Dini Bilginin Üretimi: Medrese ve İlahiyatlar. (Doktora tezi). İstanbul Üniversitesi, İstanbul.

Öztaş, M. (2006). Deizm ve Dini Hayat. (Yayınlanmamış Yüksek Lisans Tezi). Erciyes Üniversitesi, Kayseri.

Şehristani, M. (2011). el-Milel ve'n-Nihal (Mustafa Öz Çev.). İstanbul: Litera Yayıncılık.

Taylan, N. (1994). İslam düşüncesinde din felsefeleri. İstanbul: MÜİFV Yayınları.

Ülgen, H. Ziya. (1967). İslâm felsefesi. Ankara: Selçuk Yayınları.

Wood, W. A. (2011). Kant'in deizmi (Necmettin Tan Çev.). Ankara Üniversitesi İlahiyat Fakültesi Dergisi, 52(1), 327-347. doi: org/10.1501/Ilhfak_0000001069

Voltaire. (1995). Felsefe sözlüğ̈̈ (Lütfi Ay Çev.). İstanbul: MEB Yayınları.

Yeşilyurt, T. (2015). Çă̆daş inanç sorunları. Ankara: DİB Yayınları.

Zavalsı, Y. S. ve Şahin, E. (2018) Ateist ve deistlerin din algısı: üniversite öğrencileri üzerine psiko-sosyolojik bir araştırma. Tarih Kültür ve Sanat Araştırmaları Dergisi, 7(2), 567-599. doi:.org\%2F10.7596\%2Ftaksad.v7i2.1425

ETIKK ve BİLIMSEL İLKELER SORUMLULUK BEYANI

$\mathrm{Bu}$ çalışmanın tüm hazırlanma süreçlerinde etik kurallara ve bilimsel atıf gösterme ilkelerine riayet edildiğini yazar(lar) beyan eder. Aksi bir durumun tespiti halinde Afyon Kocatepe Üniversitesi Sosyal Bilimler Dergisi'nin hiçbir sorumluluğu olmayıp, tüm sorumluluk makale yazarlarına aittir. 